\title{
Proanthocyanidin-Rich Date Seed Extract Protects Against Chemically Induced Hepatorenal Toxicity
}

\author{
Atallah F. Ahmed, ${ }^{1,2}$ Jawaher H. Al-Qahtani, ${ }^{1}$ Hanan M. Al-Yousef, Mansour S. Al-Said, ${ }^{1,3}$ \\ AbdelKader E. Ashour, Mohammed Al-Sohaibani, ${ }^{4}$ and Syed Rafatullah ${ }^{3}$ \\ ${ }^{1}$ Department of Pharmacognosy, ${ }^{3}$ Medicinal, Aromatic and Poisonous Plants Research Center, \\ ${ }^{4}$ Department of Pharmacology and Toxicology, College of Pharmacy, and ${ }^{5}$ Department of Pathology, \\ King Khalid University Hospital, King Saud University, Riyadh, Saudi Arabia. \\ ${ }^{2}$ Department of Pharmacognosy, Faculty of Pharmacy, Mansoura University, Mansoura, Egypt.
}

\begin{abstract}
A hydroacetone extract was prepared from seeds of Phoenix dactylifera L. var. Khalas, which is an industrial by-product of date processing. The proanthocyanidin nature of the extract (coded as DTX) was characterized by phytochemical and nuclear magnetic resonance (NMR) analyses. The total phenol/proanthocyanidin content and antioxidant activity of DTX were estimated by Folin-Ciocalteu, vanillin-sulfuric acid, and 2,2-diphenyl-1-picrylhydrazyl (DPPH) assays, respectively. The hepatorenal protective activity of DTX was evaluated using $\mathrm{CCl}_{4}$-induced toxicity model in rats, in comparison with silymarin (SYL). Results of the histopathological examination and measurements of various hepatorenal serum indices and tissue biochemical markers demonstrated that DTX displayed marked protective potential against $\mathrm{CCl}_{4}-$ induced liver and kidney injury at $100 \mathrm{mg} / \mathrm{kg} / \mathrm{rat}$. Relative to the control $\mathrm{CCl}_{4}$-intoxicated group, pretreatment with DTX significantly $(P<.001)$ suppressed the elevated serum levels of alanine aminotransferase and aspartate aminotransferase (ALT and AST), alkaline phosphatase (ALP), $\gamma$-glutamyl transferase (GGT), total cholesterol (TC), low-density lipoprotein cholesterol (LDL-C), bilirubin, creatinine, and calcium, whereas it significantly $(P<.001)$ increased the diminished serum levels of high-density lipoprotein cholesterol (HDL-C) and total protein (TP). Moreover, DTX significantly decreased malondialdehyde (MDA) formation and increased TP synthesis in hepatorenal tissues compared with the intoxicated control. The improvement in biochemical parameters by DTX was observed in a dose-dependent manner and confirmed by restoration of normal histological features. The acute toxicity test of DTX in rats revealed safety of the extract. This study reveals that DTX enhances the recovery from xenobiotics-induced toxicity initiated by free radicals.
\end{abstract}

KEY WORDS: $\bullet$ antioxidant $\bullet$ hepatoprotective $\bullet$ nephroprotective $\bullet$ phenolics $\bullet$ Phoenix dactylifera $\bullet$ proanthocyanidins

\section{INTRODUCTION}

$\mathbf{T}$ HE SEED OF THE DATE palm tree (Phoenix dactylifera $\mathrm{L}$.), which constitutes $10-15 \%$ of the fruit weight, is a byproduct of date processing industries. ${ }^{1}$ With world production of dates reaching 9 million tons $\sim 960$ thousand tons of seeds are produced ${ }^{2}$ and being wasted or partly used as fodder, noncaffeinated coffee, or a source of dietary fibers. ${ }^{3}$ The seeds are odorless with light to dark brown color and astringent taste, and they are rich in dietary fiber (65$69 \%)$, fat $(9.9-13.5 \%)$, protein $(4.8-7.5 \%)$, and phenolics $(\sim 4 \%){ }^{4,5}$ It is estimated that date seeds possess higher total phenolic content (about 18-fold more gallic acid equivalent GAE/100 g) and antioxidant activity (about 4- to 7-fold more Trolox equivalent $/ \mathrm{g}$ ) compared to the commonly eaten date flesh. ${ }^{6}$ Recently, the phenolic content of the Khalas variety

Manuscript received 27 January 2014. Revision accepted 9 October 2014.

Address correspondence to: Atallah F. Ahmed, PhD, Department of Pharmacognosy, King Saud University (KSU), Riyadh 11451, Saudi Arabia, E-mail: afahmed@ksu.edu.sa of date seeds, as analyzed by UPLC-DAD-ESI-MS, was found to contain mainly flavan-3-ol monomers to tetramers (proanthocyanidins), in addition to minor quantities of simple phenolic acids and flavonoids. ${ }^{7}$ Al-Farsi and Lee have optimized the extraction of total phenols using a wateracetone mixture as a solvent. ${ }^{8}$

Although date seeds are readily available, few studies have been undertaken to prove their antidiabetic, ${ }^{9}$ antioxidative,${ }^{10}$ and antiviral ${ }^{11}$ potential. In this study, we aimed to evaluate the effect of a proanthocyanidin-rich extract of Khalas date seeds in combating xenobiotic-induced hepatorenal injury via oxidative stress using in vivo models.

\section{MATERIALS AND METHODS}

\section{Chemicals and analytical instruments}

All chemicals were purchased from Sigma-Aldrich (St. Louis, MO, USA). Antistax ${ }^{\circledR}$ capsules (Boehringer Ingelheim $\mathrm{GmbH}$, Ingelheim am Rhein, Germany), each contains $180 \mathrm{mg}$ dry aqueous extract of red vine leaves (Vitis vinifera L.); 
a

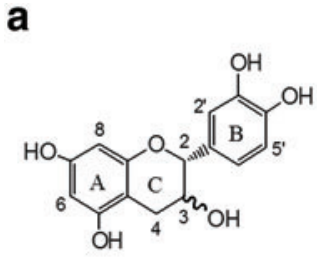

(+)-catechin $(3 \beta-\mathrm{OH})$ (-)-epicatechin (3a-OH)

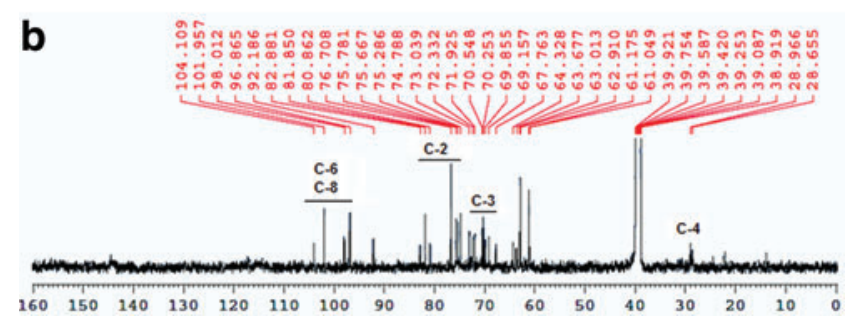

FIG. 1. Structure of common flavan-3-ols and proanthocyandins (a) and ${ }^{13} \mathrm{C}$ NMR spectrum $\left(125 \mathrm{MHz}\right.$, dimethyl sulfoxide [DMSO]- $\mathrm{d}_{6}$ ) of DTX $(25 \mathrm{mg})$, number of scans $(\mathrm{NS})=3000$, acquisition time in seconds $(\mathrm{AQ})=1.091241$ (b). NMR, nuclear magnetic resonance. Color images available online at www.liebertpub.com/jmf

batch No. B03820003. ${ }^{13} \mathrm{C}$ nuclear magnetic resonance (NMR) spectrum (Fig. 1 and Table 1) were recorded in dimethyl sulfoxide (DMSO)- $\mathrm{d}_{5}$ on a Bruker Avance DRX-500 spectrometer (College of Pharmacy, KSU). Absorbance was measured on a Specord 40 UV-VIS instrument (Jena Analytik AG, Jena, Germany) in 2,2-diphenyl-1-picrylhydrazyl (DPPH) antioxidant, vanillin-sulfuric acid, and Folin-Ciocalteu assays; on a Reflotron ${ }^{\circledR}$ Plus Analyzer (Roche Diagnostics GmbH, Mannheim, Germany) in estimation of serum parameters; and on a Shimadzu UV mini-1240 spectrophotometer (Shimadzu Europe, Milano, Italy) in other measurements.

\section{Preparation of DTX}

Ripe Khalas dates (collected from Al-Kharj region, $16 \mathrm{~kg}$ ) were purchased from the dates' market in Riyadh, Saudi Arabia. The date variety was identified by Dr. Mahmoud Abdel Aziz, College of Food and Agricultural Sciences, KSU. Seeds were manually separated from dates, thoroughly cleaned with distilled water, air dried in shadow $(2.2 \mathrm{~kg}$, $13.75 \% \mathrm{w} / \mathrm{w}$ yield), and then ground using a heavy-duty mill. The resulting powder was exhaustively extracted by $70 \%$ acetone in distilled water $(3 \mathrm{~L} \times 4)$ for 8 days and the extracts were combined and concentrated under vacuum at $40^{\circ} \mathrm{C}$ to yield a dark brown solid extract (192.68 g, 8.76\% w/w yield).

\section{Folin-Ciocalteu assay}

Total phenols in DTX were determined according to the procedure of Singleton and Rossi ${ }^{12}$ with some modifications. Briefly, aliquots $(1.0 \mathrm{~mL})$ of diluted extracts or standards (gallic acid and quercetin) in $\mathrm{MeOH}$ were mixed with $2.5 \mathrm{~mL}$ $0.2 \mathrm{~N}$ Folin-Ciocalteu reagent. After $5 \mathrm{~min}$, the reaction mixture was neutralized with $\mathrm{Na}_{2} \mathrm{CO}_{3}(2 \mathrm{~mL}, 7.5 \%$ w/v) solution. After incubation ( $2 \mathrm{~h} / \mathrm{RT})$, absorbance " $\mathrm{A}$ " of the resulting blue color was measured at $765 \mathrm{~nm}$. Calibration curves were prepared using " $\mathrm{A}$ " of different concentrations $(6.25,12.5,25,50,100$, and $200 \mu \mathrm{g} / \mathrm{mL}, n=3)$ of standards. Total phenols content was expressed as mg gallic acid or quercetin equivalent (QUE) per g extract (Table 2).

\section{Vanillin-sulfuric acid assay}

Proanthocyanidins in DTX or Antistax were estimated according to Sun et al. ${ }^{13}$ with some modifications. Samples were sonicated in $\mathrm{MeOH}$ followed by centrifugation and each supernatant was separated, evaporated to dryness, and then reconstituted in $\mathrm{MeOH}$ to make up a stock solution of $1 \mathrm{mg} / \mathrm{mL}$. To $1 \mathrm{~mL}$ of (+)-catechin (CT) solutions (18.75, $37.5,75,150$, or $300 \mu \mathrm{g} / \mathrm{mL} \mathrm{MeOH})$ or test solution $(200 \mu \mathrm{g} /$ $\mathrm{mL} \mathrm{MeOH}$ ) in a test tube, $2.5 \mathrm{~mL}$ of $1 \%$ vanillin solution in $\mathrm{MeOH}$, and $2.5 \mathrm{~mL}$ of $3.6 \mathrm{~N} \mathrm{H}_{2} \mathrm{SO}_{4}$ in $\mathrm{MeOH}$ were added. After incubation $\left(20 \mathrm{~min} / 30^{\circ} \mathrm{C}\right)$, "A" of each reaction mixture was measured at $500 \mathrm{~nm}$ and calculated using the equation: $A=\left(A_{s}-A_{b}\right)-\left(A_{c}-A_{0}\right) \cdot{ }^{14} A_{s}, A_{b}, A_{c}$, and $A_{o}$ are absorbances of solutions with the test sample, without the test sample, without vanillin, and with only $\mathrm{H}_{2} \mathrm{SO}_{4}$ (total volume, $6 \mathrm{~mL}$ ), respectively. Proanthocyanidin content was calculated from a calibration curve prepared by using A of $\mathrm{CT}$ dilutions and the above equation as \% CT w/w (Table 2).

\section{HPTLC densitometry for analysis of proanthocyandins in DTX}

The solvent mixture $\mathrm{CH}_{3} \mathrm{CN}-\mathrm{H}_{2} \mathrm{O}-\mathrm{AcOH}$ in a volume ratio of 50:50:0.5 and Merck HPTLC RP-18 $\mathrm{F}_{254}$ plates, $10 \times 10 \mathrm{~cm}$ were used as mobile phase and stationary phase, respectively. Standard (+)-catechin and DTX methanolic solutions $(1 \mu \mathrm{g} / 1 \mu \mathrm{L}$ to $10 \mu \mathrm{g} / 10 \mu \mathrm{L})$ were applied, separately, as $4 \mathrm{~mm}$ bands (in spray mode) using CAMAG automatic TLC sampler (ATS-4). After development in the

Table 1. Diagnostic ${ }^{13} \mathrm{C}$ NMR Data (Ppm) of A- and C-Rings in the Proanthocyandins of DTX in Comparison with Flavan-3-ol Monomers: (+)-Catechin and (-)-Epicatechin, and Common Proanthocyanidin Oligomers 35

\begin{tabular}{lcccc}
\hline Carbon No. & DTX proanthocyanidins content & (+)-Catechin & (-)-Epicatechin & Common proanthocyanidins \\
\hline C-2 & $76.7-82.9$ & 82.0 & 79.1 & $76.4-82.0$ \\
C-3 & $67.8-73.0$ & 67.9 & 66.8 & $66.2-73.1$ \\
C-4 & $28.7-29.0$ & 28.1 & 28.6 & $28.0-37.2$ \\
C-6 & $96.7-104.1$ & 96.7 & 96.8 & $96.1-108.6$ \\
C-8 & $96.7-104.1$ & 95.7 & 96.0 & $95.6-108.1$ \\
\hline
\end{tabular}


Table 2. Total Phenol/Proanthocyanidin Content and Antioxidant Activity of DTX

\begin{tabular}{|c|c|}
\hline Index & Value \\
\hline \multicolumn{2}{|l|}{ Phenol content ${ }^{\mathrm{a}}$} \\
\hline mg GAE/g ${ }^{\mathrm{b}}$ & $282.83 \pm 18.16$ \\
\hline mg QUE/g ${ }^{c}$ & $280.47 \pm 19.95$ \\
\hline Proanthocyanidin content $(\% \mathrm{CT} w / w)^{\mathrm{d}}$ & $49.0 \pm 0.52[6.28 \pm 0.08]^{\mathrm{e}}$ \\
\hline Antioxidant activity $\left(\mathrm{IC}_{50} \mathrm{mg} / \mathrm{mL}\right)^{\mathrm{f}}$ & $6.0[13.4]^{\mathrm{e}}[5.2]^{\mathrm{g}}$ \\
\hline
\end{tabular}

${ }^{a}$ Index was measured by Folin-Ciocalteau assay.

${ }^{\mathrm{b}}$ The linear regression equation was $\mathrm{y}=0.0212 \mathrm{x}+0.0548, \mathrm{r} 2=0.998$.

${ }^{\mathrm{c}}$ The linear regression equation was $\mathrm{y}=0.0193 \mathrm{x}+0.1714, \mathrm{r} 2=0.993$.

dIndex was measured by vanillin sulfuric acid assay.

eValues obtained by a standardized proanthocyanidin extract [Antistax ${ }^{\circledR}$ ].

${ }^{\mathrm{f}}$ Index was measured by DPPH radical scavenging assay.

${ }^{\mathrm{g}} \mathrm{A}$ value obtained by a reference antioxidant flavonoid [rutin].

GAE, gallic acid equivalent; QUE, quercetin equivalent; CT, (+) Catechin.

CAMAG automatic developing chamber (ADC-2), the developed HPTLC plates were scanned and recorded at $280 \mathrm{~nm}$. The identification of proanthocyanidin bands was based on the UV/Vis spectra traced by CAMAG TLC Scanner3 at 200-700 $\mathrm{nm}$ before and after derivatization with the specific vanillin- $\mathrm{HCl}$ spray reagent. The relative content (\%) of proanthocyandins was calculated based on area under peaks densitometrically measured at $280 \mathrm{~nm}$. The whole process of analysis was controlled by WinCATS software version1.3.4. The results are presented in Table 3 .

\section{DPPH radical scavenging assay}

The antioxidant activity of DTX was determined according to the method of Brand-Williams et al. ${ }^{15}$ at 250, 50, $10,2$, and $0.4 \mu \mathrm{g} / \mathrm{mL}$ concentrations. Each solution ( $1 \mathrm{~mL})$ was mixed with freshly prepared DPPH methanolic solution $(125 \mu \mathrm{L}$ of $1 \mu \mathrm{M})$ and $375 \mu \mathrm{L} \mathrm{MeOH}$. After incubation $\left(25^{\circ} \mathrm{C}, 30 \mathrm{~min}\right)$, the decrease ( $\left.\mathrm{I} \%\right)$ in " $\mathrm{A}$ " was measured at
$517 \mathrm{~nm}$. Inhibition percent of DPPH radical was calculated from the equation: $I \%=\left[\left(\mathrm{A}_{\text {blank }}-\mathrm{A}_{\text {sample }}\right) / \mathrm{A}_{\text {blank }}\right] \times 100$.

\section{Animals and monitoring}

Male adult Wistar albino rats (150-170 g) were obtained from the Experimental Animal Care Center, College of Pharmacy, KSU. After a 1-week adaptation period, rats were randomly divided into groups (six rats/cage) and kept at $22^{\circ} \mathrm{C} \pm 2{ }^{\circ} \mathrm{C}, 55 \%$ humidity, and $12 / 12 \mathrm{~h}$ light-dark cycle. The animals were provided with Purina chow rat diet (UARPanlab, Barcelona, Spain) and drinking water ad libitum. All treatment protocols for this study were approved by the Ethics Committee of the Experimental Animal Care Society, KSU.

\section{Acute toxicity test}

The acute toxicity of DTX was tested in rats, which were dosed in a stepwise procedure using the fixed doses of 50 $2000 \mathrm{mg} / \mathrm{kg}$ orally according to the OECD guideline No. $420 .{ }^{16}$ The animals were fasted overnight and then received DTX (suspended in 3\% gum acacia in distilled water). The animals were then observed for $3 \mathrm{~h}$ for general behavioral, neurological, and autonomic profiles and every $30 \mathrm{~min}$ for the next $3 \mathrm{~h}$ and finally for mortality after $24 \mathrm{~h}$ till 14 days.

\section{Pretreatment and $\mathrm{CCl}_{4}$-induced hepatorenal toxicity}

Five groups (I-V) of animals were used. Group I was kept as a normal control. Group II received $\mathrm{CCl}_{4}$ and served as a $\mathrm{CCl}_{4}$-intoxicated control. Groups III-V were assigned as treatment groups. Groups III and IV were pretreated with DTX at doses of 50 and $100 \mathrm{mg} / \mathrm{kg} /$ rat orally, respectively; whereas groups $\mathrm{V}$ was pretreated with silymarin (SYL) at $10 \mathrm{mg} / \mathrm{kg} / \mathrm{rat}$ orally, for 17 days. Group I and II animals received a similar volume of vehicle once daily orally. At the 16th day, groups $\mathrm{II}-\mathrm{V}$ received $\mathrm{CCl}_{4}$ in liquid paraffin

Table 3. R $_{\mathrm{f}}$ Values, Relative Content, UV Maxima of Isolated Proanthocyanidins (Before and After Derivatization), and Densitogram of DTX by HPTLC Analysis

\begin{tabular}{|c|c|c|c|c|c|}
\hline Band & $R_{f}$ value $^{\mathrm{a}}$ & $\begin{array}{c}\text { Relative } \\
\text { content }(\%)^{\mathrm{b}}\end{array}$ & $\begin{array}{l}\text { Plain UV spectral } \\
\text { data }\left(\lambda_{\max } \mathrm{nm}\right)\end{array}$ & $\begin{array}{l}\text { UV spectral data }\left(\lambda_{\max } \mathrm{nm}\right) \\
\text { after derivatization }\end{array}$ & HPTLC densitogram of DTX \\
\hline 1 & 0.51 & 04.96 & $283.1,316.9$ & 288.6 sh, $314.6,502.7$ & 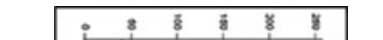 \\
\hline 2 & 0.76 & 36.42 & $283.1,316.9$ & 288.6 sh, $314.6,502.7$ & E \\
\hline 3 & 0.88 & 11.20 & $283.1,316.9$ & $288.6,314.6 \mathrm{sh}, 502.7$ & 8 \\
\hline 4 & 0.92 & 47.41 & $283.1,316.9$ & $288.6,314.6$ sh, 502.7 & \\
\hline $\mathrm{CT}$ & 0.74 & $-^{c}$ & 283.1 & $250.0,503.0$ & 8 \\
\hline
\end{tabular}

${ }^{a}$ Analysis was run using HPTLC RP-18 plate and mobile phase used: $\mathrm{CH}_{3} \mathrm{CN}-\mathrm{H}_{2} \mathrm{O}-\mathrm{AcOH}$ (50:50:0.5).

${ }^{b}$ Based on area under peak densitometrically measured at $280 \mathrm{~nm}$.

${ }^{\mathrm{c}}(+)$-Catechin $(\mathrm{CT})$ peak may be overlapped with the proanthocyanidin peak at $\mathrm{R}_{\mathrm{f}} 0.76$.

sh, shoulder. 
(1:1) at a dose of $1.25 \mathrm{~mL} / \mathrm{kg} / \mathrm{rat}$ intraperitoneally. ${ }^{17}$ After $48 \mathrm{~h}$, following $\mathrm{CCl}_{4}$ challenge, the blood was collected by cardiocentesis and serum was obtained by centrifugation at $1000 \mathrm{~g}$ for $20 \mathrm{~min}$ at $4^{\circ} \mathrm{C}$. The liver and kidney were removed for biochemical and histological assessment.

\section{Analyses of serum hepatic biochemical and lipid profile}

Serum alanine aminotransferase (ALT) and aspartate aminotransferase (AST), $\gamma$-glutamyl transferase (GGT), and alkaline phosphatase (ALP) were determined calorimetrically by methods of Reitman and Frankel ${ }^{18}$; Fiala et al. ${ }^{19}$; and King and Armstrong, ${ }^{20}$ respectively, whereas bilirubin was determined by Stiehl's method. ${ }^{21}$ Serum total cholesterol (TC), high-density lipoprotein cholesterol (HDL-C), and triglycerides (TG) were measured by the methods of Demacher and Hijamaus $^{22}$; Burstein and Scholnick ${ }^{23}$; and Foster and Dunn, ${ }^{24}$ respectively, using Roche kits (Roche Diagnostics $\mathrm{GmbH}$ ). Low-density lipoprotein cholesterol (LDL-C) and the very low-density lipoprotein cholesterol (VLDL-C) levels were calculated from the formula: LDL-C $=\mathrm{TC}-\mathrm{HDL}-\mathrm{C}-$ VLDL-C; VLDL-C $=\mathrm{TG} / 5.27 .{ }^{25}$

\section{Analyses of serum creatinine, calcium, urea, and uric acid}

Creatinine was measured by the Jaffe reaction method ${ }^{26}$ using CS604 kit (Crescent Diagnostics, Jeddah, Saudi Arabia). Calcium was determined by $o$-cresolphthalein method described by Gitelman ${ }^{27}$ using CE500 kit (Crescent Diagnostics). Urea and uric acid were determined by urease and uricase methods described by Munan et al. ${ }^{28}$ and Fossati et al. ${ }^{29}$ respectively, using Roche kits (Roche Diagnostics $\mathrm{GmbH}$ ).

\section{Determination of lipid peroxidation}

A modified method of Utley et al. was used to measure lipid peroxidation. ${ }^{30}$ The liver (or kidney) was homogenized in $0.15 \mathrm{M} \mathrm{KCl}$ at $4^{\circ} \mathrm{C}$; and the homogenate $(10 \% \mathrm{w} / \mathrm{v}, 1 \mathrm{~mL})$ was transferred into a centrifuge tube and incubated at $37^{\circ} \mathrm{C}$ for $3 \mathrm{~h}$. Aqueous trichloroacetic acid (TCA, 10\%) was then added and the mixture was centrifuged at $800 \mathrm{~g}$ for $10 \mathrm{~min}$. The supernatant $(1 \mathrm{~mL})$ was removed and mixed with aqueous thiobarbituric acid $(1 \mathrm{~mL}, 0.67 \%)$ and placed in a boiling water bath for $10 \mathrm{~min}$. The mixture was cooled, diluted with $1 \mathrm{~mL}$ distilled water, and A was read at $535 \mathrm{~nm}$. The lipid peroxidation was expressed as malondialdehyde (MDA) in $\mathrm{nmol} / \mathrm{g}$ wet tissue using a standard curve of MDA dilutions.

\section{Estimation of nonprotein sulfhydryl groups}

Tissue nonprotein sulfhydryl (NP-SH) groups were measured according to the method of Sedlak and Lindsay after homogenization in ice-cold ethylenediaminetetraacetic acid $(0.02 \mathrm{M}){ }^{31}$ The homogenate $(5 \mathrm{~mL})$ was mixed with distilled water $(4 \mathrm{~mL})$ and TCA $(50 \%, 1 \mathrm{~mL})$, shaken for $10 \mathrm{~min}$ and then centrifuged. A supernatant $(2 \mathrm{~mL})$ was mixed with Tris buffer $(4 \mathrm{~mL}, 0.4 \mathrm{M}, \mathrm{pH} 8.9)$ and 5,5'dithiobis-(2-nitrobenzoic acid) $(0.1 \mathrm{~mL})$ was then added and shaken. " $\mathrm{A}$ " was measured within $5 \mathrm{~min}$ at $412 \mathrm{~nm}$ against a reagent blank.

\section{Determination of albumin and total protein}

Serum albumin; and serum and tissue total protein (TP) were estimated according to the method of Doumas ${ }^{32}$ by CS600 and CS610 kits (Crescent Diagnostics), respectively. The principle is based on the formation of a blue/violet complex when protein peptide bonds react with $\mathrm{Cu}(\mathrm{II})$ ions in alkaline solution (biuret reaction). KNa tartrate and KI solutions were added as stabilizers. "A" was measured at $546 \mathrm{~nm}$ and protein was calculated as $\left(\mathrm{A}_{\text {sample }} / \mathrm{A}_{\text {standard }}\right) \times$ concentration of standard.

\section{Histopathological study}

The liver and kidney samples were fixed in $10 \%$ neutral buffered formalin for $24 \mathrm{~h}$ and processed using a VIP tissue processor. The processed tissues were then embedded in paraffin blocks and sections ( $5 \mu \mathrm{m}$ thickness) were cut by a rotary microtome (American Optical, Buffalo, NY, USA). Sections were stained with hematoxylin and eosin ${ }^{33}$; and then microscopically examined for pathomorphological changes.

\section{Data analysis}

Values are presented as arithmetic mean \pm standard error of the mean. Data were statistically analyzed by using oneway ANOVA followed by Dunnett's multiple comparison tests. The $P$-value $<.05$ was taken as a statistically significant difference.

\section{RESULTS}

\section{Qualitative and quantitative determination of phenolic content and antioxidant capacity of DTX}

The cherry-red color produced with vanillin- $\mathrm{HCl}$ reagent ${ }^{34}$ indicated the presence of proanthocyanidins in DTX (Fig. 1). Furthermore, ${ }^{13} \mathrm{C}$ NMR spectrum measured in DMSO- $\mathrm{d}_{6}$ showed the diagnostic carbon signals of C-ring (C-2 to C-4) and A-ring (C-6 and C-8) of flavan-3-ol monomers and their common oligomers $^{35}$ (Fig. 1 and Table 1), indicating the proanthocyanidin chemical nature of the extract.

The total phenolic content in DTX was quantified with Folin-Ciocalteu reagent as $282.83 \pm 18.16 \mathrm{mg} \mathrm{GAE} / \mathrm{g}$ or $280.47 \pm 19.95 \mathrm{mg}$ QUE/g. Moreover, the proanthocyanidin portion of total phenols was determined with a modified vanillin assay that revealed the richness of DTX in proanthocyandins, being eightfold more \%CT relative to a standard proanthocyanidin-containing extract, Antistax (Table 2).

HPTLC densitometric analysis of $0.1 \%$ w/v DTX methanolic solution indicated the presence of four major bands of proanthocyandins as depicted from their characteristic spectral data (Table 3) measured before and after derivatization with the specific vanillin- $\mathrm{HCl}$ spray reagent. Their relative percentages were found to be $4.96 \%, 11.20 \%$, $36.42 \%$, and $47.41 \%$.

The antioxidant activity of DTX was measured by DPPH radical scavenging assay. As presented in Table 2, DTX was able to reduce the blue DPPH radical solution $(125 \mu \mathrm{L}$ of $1 \mu \mathrm{M})$ into a yellow stable compound at $\mathrm{IC}_{50} 6.0 \mu \mathrm{g} / \mathrm{mL}$, being as 
Table 4. Serum Concentrations of Liver Enzymes, Bilirubin, Albumin, Total Protein, Lipids, Creatinine, Uric Acid, Urea, and Calcium from the Control and the Different Treated Groups

\begin{tabular}{|c|c|c|c|c|c|}
\hline Variables & Normal control & $\mathrm{CCl}_{4}$ & $\mathrm{CCl}_{4}+\mathrm{DTX}(50 \mathrm{mg} / \mathrm{kg})$ & $\mathrm{CCl}_{4}+\mathrm{DTX}(100 \mathrm{mg} / \mathrm{kg})$ & $\mathrm{CCl}_{4}+\mathrm{SYL}(10 \mathrm{mg} / \mathrm{kg})$ \\
\hline AST (U/L) & $75.78 \pm 4.08$ & $301.66 \pm 8.33 * * * \mathrm{a}$ & $236.33 \pm 5.00 * * * \mathrm{~b}$ & $209.00 \pm 6.15 * * * \mathrm{~b}$ & $138.33 \pm 6.79 * * * \mathrm{~b}$ \\
\hline ALT (U/L) & $29.08 \pm 2.03$ & $210.83 \pm 6.36 * * * a$ & $161.33 \pm 4.83 * * * \mathrm{~b}$ & $138.16 \pm 3.62 * * * \mathrm{~b}$ & $71.66 \pm 7.09 * * * \mathrm{~b}$ \\
\hline GGT (U/L) & $3.83 \pm 0.36$ & $17.21 \pm 0.84 * * * \mathrm{a}$ & $11.21 \pm 0.26^{* * *}$ & $9.31 \pm 0.24 * * * \mathrm{~b}$ & $5.65 \pm 0.21 * * * b$ \\
\hline $\operatorname{ALP}(\mathrm{U} / \mathrm{L})$ & $308.66 \pm 7.18$ & $681.33 \pm 14.17 * * * \mathrm{a}$ & $573.16 \pm 20.98 * * * \mathrm{~b}$ & $507.66 \pm 8.26 * * * \mathrm{~b}$ & $418.66 \pm 7.33 * * * \mathrm{~b}$ \\
\hline Bilirubin (mg/dL) & $0.58 \pm 0.01$ & $2.66 \pm 0.15 * * * \mathrm{a}$ & $1.77 \pm 0.09 * * * \mathrm{~b}$ & $1.38 \pm 0.03 * * * \mathrm{~b}$ & $1.05 \pm 0.06^{* * * \mathrm{~b}}$ \\
\hline Albumin $(\mathrm{U} / \mathrm{L})$ & $4.94 \pm 0.22$ & $1.73 \pm 0.16 * * * \mathrm{a}$ & $1.82 \pm 0.12^{\mathrm{b}}$ & $2.20 \pm 0.16^{\mathrm{b}}$ & $3.49 \pm 0.28 * * * \mathrm{~b}$ \\
\hline $\mathrm{TP}(\mathrm{g} / \mathrm{dL})$ & $9.58 \pm 0.57$ & $4.47 \pm 0.34 * * * a$ & $5.26 \pm 0.45^{b}$ & $6.86 \pm 0.30 * * * \mathrm{~b}$ & $8.02 \pm 0.38 * * * \mathrm{~b}$ \\
\hline $\mathrm{TC}(\mathrm{mg} / \mathrm{dL})$ & $102.66 \pm 4.80$ & $312.00 \pm 9.68 * * * a$ & $234.66 \pm 15.82 * * \mathrm{~b}$ & $196.00 \pm 7.93 * * * \mathrm{~b}$ & $169.33 \pm 10.61 * * * \mathrm{~b}$ \\
\hline TG (mg/dL) & $93.51 \pm 6.48$ & $237.96 \pm 4.40 * * * \mathrm{a}$ & $210.64 \pm 20.32^{\mathrm{b}}$ & $189.35 \pm 16.64 * \mathrm{~b}$ & $159.25 \pm 6.11 * * * \mathrm{~b}$ \\
\hline HDL-C (mg/dL) & $48.08 \pm 0.75$ & $21.05 \pm 1.11 * * *$ & $36.03 \pm 1.03 * * * \mathrm{~b}$ & $38.67 \pm 1.99 * * * \mathrm{~b}$ & $35.66 \pm 2.54 * * * b$ \\
\hline LDL-C (mg/dL) & $35.92 \pm 5.77$ & $243.35 \pm 9.14 * * * \mathrm{a}$ & $156.50 \pm 17.35 * * \mathrm{~b}$ & $119.45 \pm 9.11 * * * \mathrm{~b}$ & $101.68 \pm 10.42 * * *$ \\
\hline VLDL-C (mg/dL) & $18.70 \pm 1.29$ & $47.59 \pm 0.88 * * * \mathrm{a}$ & $42.12 \pm 4.06^{\mathrm{b}}$ & $37.87 \pm 3.32 * \mathrm{~b}$ & $31.85 \pm 2.34 * * * \mathrm{~b}$ \\
\hline Creatinine $(\mathrm{mg} / \mathrm{dL})$ & $1.90 \pm 0.05$ & $7.07 \pm 0.11 * * * \mathrm{a}$ & $6.50 \pm 0.18 * \mathrm{~b}$ & $5.41 \pm 0.18 * * * \mathrm{~b}$ & $6.38 \pm 0.14 * * \mathrm{~b}$ \\
\hline Uric acid (mg/dL) & $1.20 \pm 0.09$ & $6.43 \pm 0.42 * * * a$ & $5.25 \pm 0.21 * \mathrm{~b}$ & $4.78 \pm 0.25^{* * \mathrm{~b}}$ & $3.18 \pm 0.21 * * * \mathrm{~b}$ \\
\hline Urea $(\mathrm{mg} / \mathrm{dL})$ & $64.78 \pm 3.77$ & $189.66 \pm 12.09 * * * a$ & $165.55 \pm 5.27^{\mathrm{b}}$ & $146.33 \pm 4.58 * * \mathrm{~b}$ & $134.50 \pm 0.22 * * \mathrm{~b}$ \\
\hline Calcium (mg/dL) & $7.17 \pm 0.43$ & $29.52 \pm 0.84 * * * \mathrm{a}$ & $28.00 \pm 0.57^{\mathrm{b}}$ & $21.90 \pm 1.46^{* * *}$ & $9.20 \pm 0.45 * * * \mathrm{~b}$ \\
\hline
\end{tabular}

All values represent mean $\pm \operatorname{SEM}(n=6) . * P<.05 ; * * P<0.01$; ***P<.001; ANOVA, followed by Dunnett's multiple comparison test.

${ }^{\mathrm{a} A s}$ compared with normal group.

${ }^{\mathrm{b}} \mathrm{As}$ compared with $\mathrm{CCl}_{4}$ only group.

ALP, alkaline phosphatase; ALT, alanine aminotransferase; AST, aspartate aminotransferase; GGT, $\gamma$-glutamyl transferase; HDL-C, high-density lipoprotein cholesterol; LDL-C, low-density lipoprotein cholesterol; SEM, standard error of the mean; SYL, silymarin; TC, total cholesterol; TG, triglycerides; TP, total protein; VLDL-C, very low-density lipoprotein cholesterol.

equipotent as rutin and twice as potent as Antistax. The relative high antioxidant potency of DTX was thus correlated to its proanthocyanidin content. On the basis of above findings, it was expected that DTX would exhibit a substantial protective activity against in vivo $\mathrm{CCl}_{4}$-induced toxicity.

\section{Acute toxicity test of DTX}

DTX was found to be safe where no mortality or toxicity symptoms was observed in the animals that received up to a dose of $2000 \mathrm{mg} / \mathrm{kg}$ till the end of experiment (14 days).

\section{Effect of DTX on liver-related serum and tissue markers}

Pretreatment with DTX (groups III and IV) significantly $(P<.001)$ reduced the $\mathrm{CCl}_{4}$-induced elevated levels of serum
ALT, AST, ALP, GGT, and bilirubin in a dose-dependent manner (Table 4), demonstrating a capacity to restore the normal functional status of the injured hepatocytes. Moreover, the low level of serum TP induced by $\mathrm{CCl}_{4}$ liver-injury were significantly $(P<.001)$ ameliorated in rats pretreated with DTX at a dose of $100 \mathrm{mg} / \mathrm{kg}$.

The administration of DTX to the intoxicated rats markedly ameliorated the values of TC, HDL-C, and LDL-C in a dose-dependent manner (groups III and IV), with an effect similar to that attained by the standard hepatoprotective flavonolignan SYL. However, DTX at $100 \mathrm{mg} / \mathrm{kg}$ moderately diminished the $\mathrm{CCl}_{4}$-induced elevated levels of $\mathrm{TG}$ and VLDL-C relative to SYL (Table 4).

As depicted in Table 5, the level of hepatic MDA, an end product of lipid peroxidation, was significantly increased

Table 5. Tissue Concentrations of Total Protein, Malondialdehyde, and Nonprotein Sulfhydryl from Liver and Kidney of the Control and the Different Treated Groups

\begin{tabular}{|c|c|c|c|c|c|}
\hline Variables & Normal control & $\mathrm{CCl}_{4}$ & $\mathrm{CCl}_{4}+\operatorname{DTX}(50 \mathrm{mg} / \mathrm{kg})$ & $\mathrm{CCl}_{4}+\mathrm{DTX}(100 \mathrm{mg} / \mathrm{kg})$ & $\mathrm{CCl}_{4}+S Y L(10 \mathrm{mg} / \mathrm{kg})$ \\
\hline \multicolumn{6}{|l|}{ Liver } \\
\hline $\mathrm{TP}(\mathrm{g} / \mathrm{L})$ & $110.97 \pm 7.21$ & $51.09 \pm 2.52 * * * \mathrm{a}$ & $61.47 \pm 3.25 * \mathrm{~b}$ & $79.04 \pm 3.81 * * * \mathrm{~b}$ & $82.63 \pm 4.04 * * * \mathrm{~b}$ \\
\hline MDA (nmol/g) & $0.85 \pm 0.15$ & $8.39 \pm 0.39 * * * a$ & $6.22 \pm 0.47 * * b$ & $4.06 \pm 0.37 * * * \mathrm{~b}$ & $2.89 \pm 0.39 * * * b$ \\
\hline NP-SH $(\mathrm{nmol} / \mathrm{g})$ & $7.24 \pm 0.69$ & $3.36 \pm 0.46^{* * * a}$ & $4.02 \pm 0.50^{\mathrm{b}}$ & $4.85 \pm 0.33^{* b}$ & $7.03 \pm 0.52 * * * b$ \\
\hline \multicolumn{6}{|l|}{ Kidney } \\
\hline $\mathrm{TP}(\mathrm{g} / \mathrm{L})$ & $96.20 \pm 3.68$ & $36.32 \pm 2.42 * * * \mathrm{a}$ & $40.31 \pm 2.42^{\mathrm{b}}$ & $59.88 \pm 3.33 * * * \mathrm{~b}$ & $71.05 \pm 3.99 * * * \mathrm{~b}$ \\
\hline MDA (nmol/g) & $0.65 \pm 0.13$ & $9.08 \pm 0.58 * * \mathrm{a}$ & $6.08 \pm 0.70 * * b$ & $3.57 \pm 0.35 * * * \mathrm{~b}$ & $2.27 \pm 0.22 * * * b$ \\
\hline NP-SH $(\mathrm{nmol} / \mathrm{g})$ & $9.61 \pm 0.41$ & $4.95 \pm 0.40 * * * a$ & $6.35 \pm 0.29 * \mathrm{~b}$ & $6.41 \pm 0.41 * \mathrm{~b}$ & $8.63 \pm 0.37 * * * b$ \\
\hline
\end{tabular}

All values represent mean $\pm \operatorname{SEM}(n=6) . * P<.05 ; * * P<.01 ; * * * P<.001$; ANOVA, followed by Dunnett's multiple comparison test.

${ }^{a}$ As compared with normal group.

${ }^{\mathrm{b}}$ As compared with $\mathrm{CCl}_{4}$ only group.

$\mathrm{TP}$, total protein; MDA, malondialdehyde; NP-SH, nonprotein sulfhydryl. 

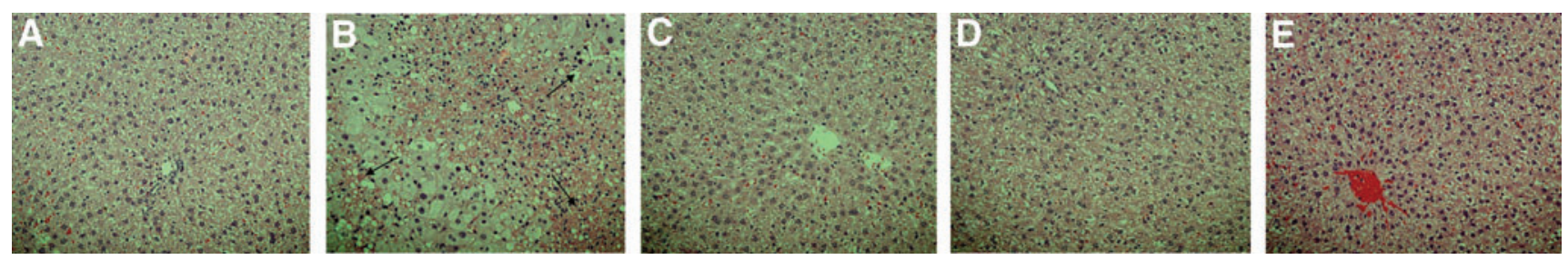

FIG. 2. Photomicrography of hematoxylin-eosin-stained sections of normal rat liver (A), liver of a $\mathrm{CCl}_{4}$-intoxicated rat (B), liver of a rat pretreated with $50 \mathrm{mg} / \mathrm{kg}$ DTX (C), liver of a rat pretreated with $100 \mathrm{mg} / \mathrm{kg}$ DTX (D), and of a rat liver pretreated with $10 \mathrm{mg} / \mathrm{kg}$ silymarin (SYL) (E). Color images available online at www.liebertpub.com/jmf

$(P<.001)$ in $\mathrm{CCl}_{4}$-intoxicated rat liver compared with that in normal controls. However, pretreatment with DTX significantly ameliorated the abnormal levels of MDA in a dosedependent manner. In the same experiment, DTX increased the level of TP diminished by $\mathrm{CCl}_{4}$-intoxication in a dosedependent manner. Similarly, DTX dose-dependently increased NP-SH level.

\section{Effect of DTX on kidney-related serum and tissue markers}

Administration of DTX at $100 \mathrm{mg} / \mathrm{kg}$ was found to significantly $(P<.001)$ inhibit the $\mathrm{CCl}_{4}$-induced high level of creatinine comparable to SYL. The inhibitory effect of DTX at $100 \mathrm{mg} / \mathrm{kg}$ on the $\mathrm{CCl}_{4}$-induced elevated calcium level was also significant $(P<.001)$. Moreover, DTX suppression of the $\mathrm{CCl}_{4}$-elevated levels of uric acid and urea was found to be more responsive and significant $(P<.01)$ at $100 \mathrm{mg} / \mathrm{kg}$ (Table 4).

In comparison with the $\mathrm{CCl}_{4}$-intoxicated kidney, pretreatment with DTX significantly lowered the level of renal MDA, being more pronounced at $100 \mathrm{mg} / \mathrm{kg}$ (Table 5). Furthermore, the higher dose of DTX $(100 \mathrm{mg} / \mathrm{kg})$ exerted a significant $(P<.001)$ increase in TP and a moderate elevation in NP-SH of pretreated kidney relative to those of control $\mathrm{CCl}_{4}$-intoxicated kidney.

\section{Effect of DTX on histopathological features of liver and kidney}

Results of histopathological assessment of the hepatic tissue (Fig. 2) were found to be correlated with the above-mentioned biochemical findings. In the control $\mathrm{CCl}_{4}$-intoxicated group, the lobular architecture of liver tissue was deformed and showed evidence of extensive pericentral vein necrosis and fatty changes with ballooning of hepatocytes and infiltration of inflammatory cells. These alterations almost disappeared and liver parenchyma returned to its normal status in rats pretreated with DTX at $100 \mathrm{mg} / \mathrm{kg}$ or with SYL at $10 \mathrm{mg} / \mathrm{kg}$, whereas DTX at $50 \mathrm{mg} / \mathrm{kg}$ exerted minimal fatty changes and necrosis.

The kidney in the control $\mathrm{CCl}_{4}$-intoxicated group showed necrosis, loss of tubular details, degeneration/shrinkage of glomeruli and Bowman's capsules, and infiltration of inflammatory cells. Rats pretreated with DTX exhibited dosedependent correction of renal injury as demonstrated by improved tubular and glomerular architecture and reduced inflammatory cells. Therefore, a better correction was attained by DTX at $100 \mathrm{mg} / \mathrm{kg}$ comparable to SYL at the dose of $10 \mathrm{mg} / \mathrm{kg}$ (Fig. 3).

\section{DISCUSSION}

Many dietary modifications and chemoprevention are considered to be effective approaches against the health hazards induced by oxidative stress. Various studies have shown that several xenobiotics cause generation of free radicals, which play a major role in initiation of oxidative stress-related diseases. Extensive in vivo studies on rodents have demonstrated that $\mathrm{CCl}_{4}$ causes injuries to liver, ${ }^{36}$ kidney, ${ }^{37,38}$ and many organs via production of electrophilic trichloromethyl $\left(\bullet \mathrm{CCl}_{3}\right)$ and peroxy trichloromethyl $\left(\bullet \mathrm{OOCCl}_{3}\right)$ radicals. ${ }^{39,40}$ Production of such reactive free radicals from halogenated alkanes by the metabolizing activity of cytochrome P450 2E1 (CYP2E1) was reported to induce hepatotoxicity ${ }^{40,41}$ and nephrotoxicity. ${ }^{42}$ These free radicals initiate lipid peroxidation and protein deterioration $^{39,43}$ with a subsequent alteration of cellular membrane
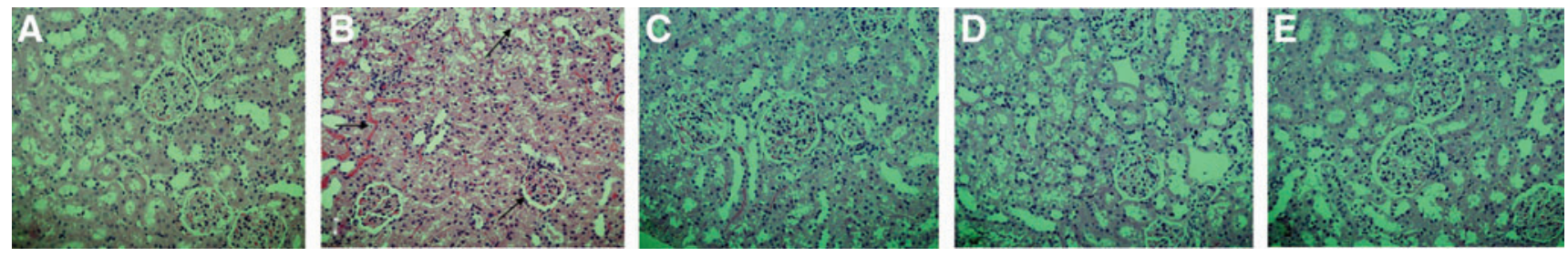

FIG. 3. Photomicrography of hematoxylin-eosin-stained sections of normal rat kidney (A), kidney of a $\mathrm{CCl}_{4}$-intoxicated rat (B), kidney of a rat pretreated with $50 \mathrm{mg} / \mathrm{kg}$ DTX (C), kidney of a rat pretreated with $100 \mathrm{mg} / \mathrm{kg}$ DTX (D), and kidney of a rat pretreated with $10 \mathrm{mg} / \mathrm{kg} \mathrm{SYL} \mathrm{(E).}$ Color images available online at www.liebertpub.com/jmf 
permeability and function, leakage of intracellular enzymes into serum, ${ }^{44,45}$ and other abnormal biochemical and histopathological changes in tissues. ${ }^{46}$ Moreover, the increase in concentration of free peroxide radical and unsaturated fatty acid peroxides can induce alterations in the cholesterol profile and lipid metabolism along with induction of oxidative DNA damage, including the formation of DNA adducts and chromosomal alterations. ${ }^{47,48}$ Additionally, the level of NP-SH, for example, glutathione (GSH), the nonenzymatic part of the antioxidant defense, and antioxidant enzymes (SOD, GPX, and CAT) decrease in the tissues due to their rapid consumption after combatting free radicalinduced oxidative stress. ${ }^{49}$ Lipid peroxidation and damage of hepatocyte membranes initiated by the reactive oxygen species (ROS) generated by $\mathrm{CCl}_{4}$ was reported to be followed by the release of a myriad of growth factors, inflammatory mediators, and prostaglandins from activated hepatic macrophages, which potentiate $\mathrm{CCl}_{4}$-induced hepatic injury by further generation of a variety of ROS. ${ }^{50}$ Therefore, inhibition and/or scavenging of intracellular ROS would play a critical role in preventing liver and kidney diseases.

Proanthocyanidins are the most abundant polyphenols in human diets and mainly composed of dimers, oligomers, and polymers of flavan-3-ols: (+)-catechin, (-)-epicatchin, and their gallic acid esters. They possess powerful antioxidant properties, and consequently therapeutic benefit against oxidative stress-related diseases. ${ }^{51,52}$ The antioxidant activity of proanthocyanidins is principally based on the properties of their phenolic hydroxyl groups, which serve as electron or hydrogen donors to terminate the free radical chain reaction yielding a stable phenolic radical. ${ }^{48,53}$ In this study we prepared a hydroacetone extract (DTX) from date seeds, which proved to be highly rich in proanthocyanidins as identified by vanillin reaction, and by HPTLC chromatographic and NMR spectroscopic analyses (Fig. 1 and Tables 1 and 3). Thus, DTX showed a powerful in vitro free radical scavenging capacity (Table 2 ). This prompted us to evaluate the protective potentiality of DTX against $\mathrm{CCl}_{4-}$ induced free radical-mediated hepatic and renal damage on the basis of biochemical and histopathological evidence.

This study revealed that $\mathrm{CCl}_{4}$ significantly increased the levels of serum ALT, AST, GGT, and ALP, which indicated acute hepatocyte injuries, altered membrane integrity, and consequently enzyme leakage. However, on pretreatment with DTX, the pathological levels of these enzymes were remarkably restored (Table 4), indicating the ability of DTX to protect hepatocytes against the deleterious effect of $\mathrm{CCl}_{4}$-derived free radicals. The $\mathrm{CCl}_{4}$ induced enhanced lipid peroxidation, which is marked by high levels of MDA, was thus significantly normalized in liver tissue on pretreatment with this proanthocyanidincontaining extract (Table 5). Furthermore, the significant decrease in the serum levels of bilirubin indicated that bilirubin was rapidly and selectively taken up into the liver as a function of healthy hepatocyte membranes maintained on pretreatment with DTX relative to that of intoxicated control (Table 4).
Administration of $\mathrm{CCl}_{4}$ significantly increased serum TG, TC, LDL-C, and VLDL-C while decreased serum HDL-C (Table 4), an effect that was found to be in agreement with previous studies. ${ }^{47,54}$ However, the increased serum concentrations of TC and LDL-C, and the decreased level of HDL-C, were found to be greatly ameliorated upon pretreatment with the proanthocyanidin-rich DTX. Studies with animal models reported that proanthocyanidins significantly decrease plasma concentration of TG (in hypotriglyceridemia), TC, and LDL-C along with an increase in HDL-C. ${ }^{55}$ Moreover, Montagut et al. ${ }^{56}$ concluded that proanthocyanidins may be largely responsible for inhibiting TG and Apolipoprotein B secretion (a marker of VLDL) by hepatic cells. It also was found that proanthocyanidins repress the expression of 3-hydroxy-3-methyl-glutaryl-CoA (HMG-CoA) reductase, HMG-CoA synthetase, and other enzymes involved in cholesterol biosynthesis. ${ }^{57}$ Proanthocyanidins also increase the CYP7A1 activity, which has a role in the transformation of cholesterol into bile acids. Finally, the insulin-like effect of proanthocyanidins in conjunction with the activation of farnesoid $\mathrm{X}$ receptor (FXR) may collaborate in the repression of VLDL secretion and the hypotriglyceridemia. ${ }^{58}$

The present results also revealed that the concentration of TP in the serum and hepatorenal tissues were markedly decreased after $\mathrm{CCl}_{4}$ challenge, in agreement with previous studies. ${ }^{17,54}$ The interpretation for the depletion of TP in $\mathrm{CCl}_{4}$-intoxicated animals may be due to the relationship between the damage occurring to DNA via free radicals and consequently the protein expression. Therefore, due to the free radical scavenging properties of proanthocyandins, pretreatment with DTX significantly increased these TP levels. Better levels of liver functionrelated enzymes and MDA along with those of TP and lipid profile in hepatic tissue have been achieved by administration of DTX in intoxicated animals. These findings indicated a preservation of biomembrane integrity, induction of protein synthesis, and stability of cholesterol metabolism in hepatocytes against free radical-induced oxidative stress, respectively. This subsequently led to a marked parallel restoration of the histological features of the liver (Fig. 2).

In this study, we also investigated the protective effects of DTX against $\mathrm{CCl}_{4}$-induced nephrotoxicity on relevant oxidative stress parameters, including renal MDA and NP-SH levels, renal injury serum biomarkers (creatinine, uric acid, urea, and calcium), and renal histopathology. Nephrotoxicity was evidenced by a significant alteration of these parameters in the $\mathrm{CCl}_{4}$-intoxicated group when compared with those of controls in the same way as previously reported ${ }^{54,59}$ Pretreatment with DTX markedly decreased the elevated levels of creatinine, urea, uric acid, and calcium; significantly corrected the levels of tissue MDA and TP; and improved the histopathological features in renal tissue (Tables 4 and 5 and Fig. 3).

With regard to the antioxidant defense system, $\mathrm{CCl}_{4}$ treatment significantly reduced the total content of NP-SH (e.g., GSH), which is considered as an important 
nonenzymatic antioxidant defense against lipid oxidative damage in the liver and kidney eliminating the hydrogen peroxide, peroxyl, and hydroxyl radicals formed. Therefore, NP-SH-dependent enzymes such as glutathione peroxidase, reductase, and S-transferase (GPx, GR, and GST, respectively), along with other antioxidant enzymes catalase (CAT) and superoxide dismutase (SOD) will also be expected to be negatively affected flowingly. In our study, the level of NP-SH content was partially restored in the hepatorenal tissues on pretreatment with DTX at dose $100 \mathrm{mg} /$ $\mathrm{kg} / \mathrm{rat}$. However, another study proved that treatment with proanthocyanidins in a higher dose $(400 \mathrm{mg} / \mathrm{kg} / \mathrm{rat})$ significantly increased GSH along with a marked restoration in antioxidant enzymes SOD, GPX, and CAT levels in $\mathrm{CCl}_{4}-$ treated rats. ${ }^{49}$

The overall hepatorenal protection may be explained by many characteristics of DTX. DTX contained high amount of proanthocyanidins $(49.0 \% \mathrm{CT} \pm 0.52 \% \mathrm{CT} \mathrm{w} / \mathrm{w})$, which conducted high antioxidant potential through their direct free radical scavenging activity, ${ }^{53}$ as revealed by the in vitro DPPH assay, by the in vivo dose-dependent decrease of the lipid peroxide marker MDA, and by the increase of the nonenzymatic antioxidant NP-SH system. Proanthocyanidins can also effectively suppress $\mathrm{CCl}_{4}$-induced cytosolic CYP2E1 expression and thus inhibit the CYP2E1 enzyme from generating free radicals from $\mathrm{CCl}_{4}$, thereby preventing the cascade that causes oxidative stress and liver injury. ${ }^{49}$ Moreover, proanthocyandins have shown a strong ability to chelate iron, which has been reported to exert some cytoprotective effects, such as decreasing iron-mediated free radical formation. ${ }^{60}$

In conclusion, administration of hydroacetone extract of date seeds was experimentally demonstrated to be safe, and remarkably protected against chemically induced hepatorenal injury. This protection could be attributed to the total phenol/proanthocyanidin content, which can suppress the oxidative stress induced by xenbiotic-generating free radicals with the subsequent restoration of the physiological and histological features of the susceptible organs. The results suggest that date seeds can serve as an invaluable and highly available source of natural antioxidants, food additives, or dietary supplements for increasing the quality of life. The evidence-based protective activity achieved in this preclinical study provides convincing evidence to support further clinical study of standardized date seed extracts in the treatment of oxidative stress-related liver and kidney diseases.

\section{ACKNOWLEDGMENT}

The authors would like to extend their sincere appreciation to the Deanship of Scientific Research at King Saud University for its funding of this research through the Research Group Project no RGP-VPP-272.

\section{AUTHOR DISCLOSURE STATEMENT}

The authors have declared that there are no conflicts of interest.

\section{REFERENCES}

1. Hussein AS, Alhadrami GA, Khalil YH: The use of dates and dates pits in broiler starter and finisher diets. Bioresour Technol 1998;66:219-223.

2. FAO: Statistical Databases. http://faostat.fao.org (accessed June 2010).

3. Baliga MS, Baligab BRV, Kandathilc SM, Bhatd HP, Vayalile PK: A review of the chemistry and pharmacology of the date fruits (Phoenix dactylifera L.). Food Res Int 2011;44:18121822.

4. Al-Showiman SS, BaOsman AA: Protein and amino acid contents of some Saudi Arabian date plam seeds (Phoenix dactylifera L.). Arab Gulf J Res 1992;10:1-9.

5. Hamada JS, Hashim IB, Sharif FA: Preliminary analysis and potential uses of date pits in foods. Food Chem 2002;76:135137.

6. Al-Farsi M, Alasalvar C, Al-Abid M, Al-Shoaily K, Al-Amry M, Al-Rawahy F: Compositional and functional characteristics of dates, syrups, and their by-products. Food Chem 2007;104:943947.

7. Habib HM, Platat C, Meudec E, Cheynier V, Ibrahim WH: Polyphenolic compounds in date fruit seed (Phoenix dactylifera): characterisation and quantification by using UPLC-DAD-ESIMS. J Sci Food Agric 2014;94:1084-1089.

8. Al-Farsi MA, Lee CY: Nutritional and functional properties of dates: a review. Crit Rev Food Sci Nutr 2008;48:877-887.

9. El-Fouhil AF, Ahmed AM, Darwish HH: Hypoglycemic effect of an extract from date seeds on diabetic rats. Saudi Med J 2010; 31:747-751.

10. Habib HM, Ibrahim WH: Effect of date seeds on oxidative damage and antioxidant status in vivo. J Sci Food Agric 2011; 91:1674-1679.

11. Jassim SA, Naji MA: In vitro evaluation of the antiviral activity of an extract of date palm (Phoenix dactylifera L.) pits on a Pseudomonas phage. Evid Based Complement Alternat Med 2010;7:57-62.

12. Singleton VL, Rossi JA: Colorimetry of total phenolics with phosphomolybdic-phosphotungstic acid reagents. Am J Enol Vitic 1965;16:144-158.

13. Sun B, Ricardo-da-Silva JM, Spranger I: Critical factors of vanillin assay for catechins and proanthocyanidins. J Agric Food Chem 1998;46:4267-4274.

14. Nakamura Y, Tsuji S, Tonogai Y: Analysis of proanthocyanidins in grape seed extracts, health foods and grape seed oils. $J$ Health Sci 2003;49:45-54.

15. Brand-Williams WW, Cuvelier ME, Berset C: Use of a free radical method to evaluate antioxidant activity. Food Sci Technol 1995;28:25-30.

16. OECD: OECD Guidelines for Testing of Chemicals. Acute Oral Toxicity. 2001. www.oecd.org/chemicalsafety/risk-assessment/ 1948362.pdf (accessed 2014).

17. Al-Said MS, Mothana RA, Al-Sohaibani MO, Rafatullah S: Ameliorative effect of Grewia tenax (Forssk) fiori fruit extract on $\mathrm{CCl}_{4}$-induced oxidative stress and hepatotoxicity in rats. $J$ Food Sci 2011;76:T200-T206.

18. Reitman S, Frankel S: A colorimetric method for the determination of serum glutamic oxalacetic and glutamic pyruvic transaminases. Am J Clin Pathol 1957;28:56-63.

19. Fiala S, Fiala AE, Dixon B: Gamma-glutamyl transpeptidase in transplantable chemically induced rat hepatomas and 
spontaneous mouse hepatomas. J Natl Cancer Inst 1972;48: 1393-1409.

20. King EJ, Armstrong AR. Calcium, phosphorus and phosphate. In: Practical Clinical Biochemistry (Varley H, ed.). CBS Publishers, New Delhi, 1988, p. 458.

21. Stiehl A: Hyperbilirubinemia in liver diseases. Fortschr Med 1982;100:842-845.

22. Demacher PNM, Hijamaus AGM: A study of the use of polyethylene glycol in estimating cholesterol. Clin Chem 1980;26: 1775-1778.

23. Burstein M, Scholnick HR: Turbidimetric estimation of chylomicrons and very low density lipoproteins in human sera after precipitation by sodium lauryl sulfate. Biomedicine 1973; 19:16-19.

24. Foster LB, Dunn RT: Stable reagents for the determination of serum triglycerides by a colorimetric Hantzch condensation method. J Clin Chem 1973;19:338-340.

25. Friedward WT, Levy R, Fradrickson DS: Estimation of concentration of low-density lipoprotein cholesterol in plasma without the use of preparative ultracentrifuge. Clin Chem 1972; 19:449-452.

26. Fabing DL, Erthinghausen G: Automated reaction rate for determination of serum creatinine with the centrifichem. Clin Chem 1971;17:696-702.

27. Gitelman HJ: An improved automatic procedure for the determination of calcium in biological specimens. Anal Biochem 1967; 18:521-531.

28. Munan L, Kelly A, PetitClerc C, Billon B: Associations with body weight of selected chemical constituents in blood: epidemiologic data. Clin Chem 1978;24:772-777.

29. Fossati P, Prencipe L, Berti G: Use of 3,5-dichloro-2-hydroxybenzenesulfonic acid/4-aminophenazone chromogenic system in direct enzymic assay of uric acid in serum and urine. Clin Chem 1980;26:227-231.

30. Utley HC, Bernheim F, Hochslein P: Effect of sulfhydryl reagent onperoxidation in microsome. Arch Biochem Biophys 1967;260: 521-531.

31. Sedlak J, Lindsay RH: Estimation of total, protein-bound, and nonprotein sulfhydryl groups in tissue with Ellman's reagent. Anal Biochem 1968;25:192-205.

32. Doumas BT: Standards for total serum protein assays-A collaborative study. Clin Chem 1975;21:1159-1166.

33. Culling CFA: Handbook of Histopathological and Histochemical Techniques. Butterworth, London, 1974.

34. Bate-Smith EC, Lerner NH: Leuco-anthocyanins. 2. Systematic distribution of leuco-anthocyanins in leaves. Biochem J 1954; 58:126-132.

35. Porter LJ, Newman RH, Foo LY, Wong H, Hemingway RW: Polymeric proanthocyanidins. 13C-NMR studies of procyanidins. J Chem Soc Perkin Trans 1982;1:1217-1221.

36. Lin HM, Tseng HC, Wang CJ, Lin JJ, Lo CW, Chou FP: Hepatoprotective effects of Solanum nigrum Linn extract against $\mathrm{CCl}_{4}$-induced oxidative damage in rats. Chem Biol Interact 2008; 171:283-293.

37. Khan RA, Khan MR, Sahreen S, Bokhari J: Prevention of $\mathrm{CCl}_{4-}$ induced nephrotoxicity with Sonchus asper in rat. Food Chem Toxicol 2010;48:2469-2476.
38. Perez AJ, Courel M, Sobrado J, Gonzalez L: Acute renal failure after topical application of carbon tetrachloride. Lancet 1987;1: 515-516.

39. Recknagel RO, Glende EA Jr., Dolak JA, Waller RL: Mechanisms of carbon tetrachloride toxicity. Pharmacol Ther 1989;43: 139-154.

40. Takahashi S, Takahashi T, Mizobuchi S, Matsumi M, Morita K, Miyazaki M, Namba M, Akagi R, Hirakawa M: Increased cytotoxicity of carbon tetrachloride in a human hepatoma cell line overexpressing cytochrome P450 2E1. J Int Med Res 2002; 30:400-405.

41. Kenna JG, Jones RM: The organ toxicity of inhaled anesthetics. Anesth Analg 1995;81(6 Suppl):S51-S66.

42. Constan AA, Sprankle CS, Peters JM, Kedderis GL, Everitt JI, Wong BA, Gonzalez FL, Butterworth, BE: Metabolism of chloroform by cytochrome P450 2E1 is required for induction of toxicity in the liver, kidney, and nose of male mice. Toxicol Appl Pharmacol 1999;160:120-126.

43. Abraham P, Wilfred G, Cathrine SP: Oxidative damage to the lipids and proteins pf the lungs, testis and kidney of rats during carbon tetrachloride intoxication. Clin Chim Acta 1999;289:177-179.

44. Recknagel RO: Carbon tetrachloride hepatotoxicity status quo and future prospects. Trends Pharmacol Sci 1983:129-130.

45. Nakamura T, Fujii T, Ichihara A: Enzyme leakage due to change of membrane permeability of primary cultured rat hepatocytes treated with various hepatotoxins and its prevention by glycyrrhizin. Cell Biol Toxicol 1985;1:285-295.

46. Halliwell B: Biochemistry of oxidative stress. Biochem Soc Trans 2007;35(Pt 5):1147-1150.

47. Khan RA, Khan MR, Sahreen S: $\mathrm{CCl}_{4}$-induced hepatotoxicity: protective effect of rutin on p53, CYP2E1 and the antioxidative status in rat. BMC Complement Altern Med 2012;12:178.

48. Chen F, Zhang L, Zong S, Xu S, Li X, Ye Y: Antioxidant capacity and proanthocyanidin composition of the bark of Metasequoia glyptostroboides. Evid Based Complement Alternat Med 2014;2014:136203.

49. Dai N, Zou Y, Zhu L, Wang HF, Dai MG: Antioxidant properties of proanthocyanidins attenuate carbon tetrachloride $\mathrm{CCl}_{4}$ induced steatosis and liver injury in rats via CYP2E1 regulation. J Med Food 2014;17:663-669

50. Sudo K, Yamada Y, Moriwaki H, Saito K, Seishima M: Lack of tumor necrosis factor receptor type 1 inhibits liver fibrosis induced by carbon tetrachloride in mice. Cytokine 2005;29:236-244.

51. Ferreira D, Slade D: Oligomeric proanthocyanidins: naturally occurring O-heterocycles. Nat Prod Rep 2002;19:517-541.

52. Han X, Shen T, Lou H: Dietary polyphenols and their biological significance. Int J Mol Sci 2007;8:950-988.

53. Lee SE, Lee HS, Ahn YJ: Scavenging effect of plant derived materials on free radicals and active oxygen species. Agric Chem Biotechnol 1999;42:40-44.

54. Al-Yahya M, Mothana R, Al-Said M, et al:: Attenuation of $\mathrm{CCl}_{4}$ induced oxidative stress and hepatonephrotoxicity by Saudi Sidr honey in rats. Evid Based Complement Alternat Med 2013;2013: 569037.

55. Blade C, Arola L, Salvado MJ: Hypolipidemic effects of proanthocyanidins and their underlying biochemical and molecular mechanisms. Mol Nutr Food Res 2010;54:37-59. 
56. Montagut G, Baiges I, Valls J, et al: : A trimer plus a dimergallate reproduce the bioactivity described for an extract of grape seed procyanidins. Food Chem 2009;116:265-270.

57. Del Bas JM, Ricketts Ml, Vaqué M, Vaque M, Sala E, Quesada H, Ardevol A, Salvadó MJ, Blay M, Arola L, Moore DD, Pujadas G, Fernandez-Larrea J, Bladé C: Dietary procyanidins enhance transcriptional activity of bile acidactivated FXR in vitro and reduce triglyceridemia in vivo in a FXR-dependent manner. Mol Nutr Food Res 2009 53: 805-814.
58. Julius U: Influence of plasma free fatty acids on lipoprotein synthesis and diabetic dyslipidemia. Exp Clin Endocrinol Diabetes 2003;111:246-250.

59. Makni M, Chtourou Y, Garoui EM, Boudawara T, Fetoui H: Carbon tetrachloride-induced nephrotoxicity and DNA damage in rats: protective role of vanillin. Hum Exp Toxicol 2012;31:844-852.

60. Wu T-H, Liao J-H, Hsu F-L, et al:: Grape seed pranthocyanidin extract chelates iron and attenuates the toxic effects of 6-hydroxydopamine: implications for Parkinson's disease. J Food Biochem 2010;34:244-262. 